\title{
Broilers perform better on short or step-up photoperiods
}

\author{
P.D. Lewis ${ }^{\#}$ and R.M. Gous \\ Animal and Poultry Science, School of Agricultural Sciences and Agribusiness, University of KwaZulu-Natal, \\ Scottsville 3209, South Africa
}

\begin{abstract}
Rearing broilers on 6-h photoperiods and transferring them to $23 \mathrm{~h}$ at $21 \mathrm{~d}$ has been shown to reduce mortality and the incidence of leg disorders without adversely affecting final body weight or feed conversion efficiency. However, in many countries, welfare codes for meat chickens currently stipulate a minimum photoperiod of $8 \mathrm{~h}$, and are likely to specify a minimum uninterrupted dark period of $8 \mathrm{~h}$ in the future. This paper reports a study of the response of two genotypes of broiler females to a lighting regimen that complies with these requirements: an initial 8-h photoperiod followed by a 16-h photoperiod from 21 to $42 \mathrm{~d}$. Constant 8- and 16-h photoperiods were provided as controls. The two breeds responded similarly to all lighting treatments. Constant 8-h and photostimulated birds had significantly heavier body weights, and strong tendencies towards larger feed intakes and superior feed conversion, than the 16-h controls. Lighting treatment had no significant effect on mortality or the incidence of leg problems. Ross birds had a significantly slower growth to $21 \mathrm{~d}$, higher feed intake after $21 \mathrm{~d}$, and inferior feed conversion efficiency throughout than Cobb birds. Ross birds had significantly lower mortality and fewer leg disorders than Cobb, due possibly to their slower initial growth.
\end{abstract}

Keywords: Photoperiod, broiler growth, feed conversion efficiency

${ }^{\#}$ Corresponding author. E-mail: northcot.7hg@dsl.pipex.com

\section{Introduction}

Since the beginning of the broiler industry in the 1950s, though less so now, it has been common practice to provide either continuous (LL) or near continuous illumination in the belief that this maximizes feed intake and growth rate (Moore, 1957; Beane et al., 1962; 1965; Morris, 1967; Weaver \& Siegel, 1968; Classen, 1992). In contrast, Skoglund et al. (1966) observed differences of no more than $3.4 \%$ in feed intake and $2.5 \%$ in body weight among 3,6, $12 \mathrm{~h}$ and LL groups, with $12 \mathrm{~h}$ not significantly different from LL. More recently, Renden et al. (1992; 1993; 1996) and Gordon \& Tucker (1995) found no significant differences in either feed intake or body weight among broilers given photoperiods varying between 8 and $23 \mathrm{~h}$. However, these later findings showed important interactions between age and the response to photoperiod: feed intake and growth rate were positively correlated with photoperiod during the initial $21 \mathrm{~d}$, but negatively correlated thereafter, especially when the daylength was $\geq 12 \mathrm{~h}$.

Although photoperiod only minimally affects performance, longer daylengths detrimentally influence most aspects of broiler welfare, and do so at all ages. Longer photoperiods and LL are associated with an increase in total mortality and a higher incidence of leg disorders (Buckland et al., 1976; Renden et al., 1993; 1996; Gordon \& Tucker, 1995), and the development of various forms of ocular abnormality (Jensen \& Matson, 1957; Shutze et al., 1960; Whitley et al., 1984; Oishi \& Murakami, 1985; Li et al., 1995; Stone et al., 1995).

The slower initial growth, but subsequent compensatory weight gain of broilers kept on shorter photoperiods, and the closer connection of skeletal development with age than body weight (Wise, 1970), stimulated the research of lighting regimens that involved a 6-h daylength to 14 or $21 \mathrm{~d}$ and a 23-h, or step up to 23-h, daylength thereafter as a technique for reducing mortality and improving skeletal integrity (Classen \& Riddell, 1989, Classen et al., 1991; Renden et al., 1991; 1992; 1993; 1996; Blair et al., 1993). The programmes consistently improved liveability to $\geq 42 \mathrm{~d}$, reduced the incidences of sudden death syndrome and leg disorders, improved feed conversion efficiency, and had no adverse effect on body weight; though the improvements were greater for males than females. Despite the clear benefits to bird health, the use of 6- and 23-h photoperiods are likely to be prohibited in future poultry welfare codes. Already, laying hens in the European Union must have at least $8 \mathrm{~h}$, and growing turkeys $4 \mathrm{~h}$ but ideally $8 \mathrm{~h}$, of uninterrupted 
darkness, and, in the UK, broilers must be given at least $8 \mathrm{~h}$ of light and not less than 30 min of darkness. This paper describes the findings of a trial in which broilers were started on $8 \mathrm{~h}$ and transferred abruptly to $16 \mathrm{~h}$ at $21 \mathrm{~d}$, or maintained on 8 or $16 \mathrm{~h}$ throughout.

\section{Materials \& Methods}

Cobb 500 and Ross 308 female broilers, which had been feather sexed and vent sexed to exclude males, were placed at $1 \mathrm{~d}$ of age on the litter floor in each of nine lightproof rooms. Each room was divided into two pens with a mesh fence, and 200 Cobb or 200 Ross birds placed in each pen at a stocking density of $8.4 / \mathrm{m}^{2}$. All birds were given constant illumination for the first day, then three rooms were randomly allocated to each of three lighting regimens from $2 \mathrm{~d}$ : constant $8 \mathrm{~h}$, constant $16 \mathrm{~h}$, or $8 \mathrm{~h}$ to $21 \mathrm{~d}$ and $16 \mathrm{~h}$ from 22 to 42 $\mathrm{d}$ (INC) (3 lighting treatments $\mathrm{x} 3$ rooms $\mathrm{x} 2$ breeds $\mathrm{x} 200$ birds $=3600$ birds). In each pen light was provided by two $11 \mathrm{~W}$ compact warm-white fluorescent lamps located $1.8 \mathrm{~m}$ above the floor, giving a mean illuminance of $29 \pm 2.3 \mathrm{lux}$ at a height of $20 \mathrm{~cm}$. All groups received the same feeding regimen: a proprietary broiler starter crumb (12.8 MJ ME $/ \mathrm{kg}, 200 \mathrm{~g}$ crude protein $/ \mathrm{kg}$ ) to $14 \mathrm{~d}$, a broiler grower pellet (12.8 MJ ME $/ \mathrm{kg}, 160 \mathrm{~g}$ crude protein $/ \mathrm{kg}$ ) 15 to $28 \mathrm{~d}$, and a broiler finisher pellet (13.0 MJ ME $/ \mathrm{kg}, 160 \mathrm{~g}$ crude protein $/ \mathrm{kg}$ ) 29-42 d. All feed was delivered from manually filled hanging tube feeders.

A sample of 60 birds from each pen were bulk weighed at 7-d intervals between 7 and $35 \mathrm{~d}$, and all birds bulk were weighed at $42 \mathrm{~d}$. Feed was weighed back every $7 \mathrm{~d}$. Mortality was recorded daily, and any ailing birds examined for signs of leg disorder and culled if appropriate. All data were analysed using a 2-way ANOVA with light and breed as variables (Analytical Software, 2003). There were no significant light $\mathrm{x}$ breed interactions, so this term was dropped from the model. Significant differences between treatments were identified using a Students $t$ test.

\section{Results}

Lighting did not affect feed intake, growth, or feed conversion efficiency to $21 \mathrm{~d}(\mathrm{P}>0.05)$. The constant 8 -h and INC birds had higher body weight gains $(\mathrm{P}<0.01)$ and more efficient feed conversion efficiency $(\mathrm{P}<0.05)$, and the 8-h birds a higher feed intake $(\mathrm{P}<0.05)$, than 16 -h birds between 22 and $42 \mathrm{~d}$ (Table 1). Overall to $42 \mathrm{~d}$, the 8 -h and INC birds had a higher feed intake $(\mathrm{P}=0.15)$ and heavier body weights $(\mathrm{P}<0.05)$ than the 16 -h birds. The INC birds converted feed more efficiently than the $16-\mathrm{h}$ birds $(\mathrm{P}<0.05)$, with 8-h birds intermediate. Lighting treatment had no effect $(\mathrm{P}>0.05)$ on mortality, culling, or leg problems at any age (Table 2 ).

Feed intakes were similar, but Cobb had a heavier body weight at $(\mathrm{P}<0.05)$, and converted feed more efficiently to $(\mathrm{P}<0.01) 21 \mathrm{~d}$ than Ross (Table 3$)$. Body weight gain between 22 and $42 \mathrm{~d}$ was similar for the two breeds $(\mathrm{P}>0.05)$, but, in this period, Ross consumed more feed $(\mathrm{P}<0.01)$, though converted it less efficiently $(\mathrm{P}=0.058)$, than Cobb. Body weights at $42 \mathrm{~d}$ did not differ $(\mathrm{P}>0.05)$, but Ross had a higher feed intake $(\mathrm{P}<0.01)$ and converted feed less efficiently $(\mathrm{P}<0.01)$ to $42 \mathrm{~d}$ than Cobb. There were no culls or leg problems in the first $21 \mathrm{~d}$, and mortality was similar $(\mathrm{P}>0.05)$ for the two breeds (Table 3$)$, but in the final $21 \mathrm{~d}$ and overall to $42 \mathrm{~d}$, Ross had lower mortality $(\mathrm{P}<0.05)$ and lower incidences of culling and leg problems $(\mathrm{P}<0.01)$ than Cobb.

\section{Discussion}

The non-significant differences between the constant 8 -h and $16-\mathrm{h}$ groups for feed intake and body weight gain to $21 \mathrm{~d}$ and the higher feed intakes and faster growth by the 8-h birds between 22 and $42 \mathrm{~d}$ (Table 1) contrast with the significantly lower 8-h values at $21 \mathrm{~d}$ but similar values at $42 \mathrm{~d}$ reported by Gordon \& Tucker (1995). This may be the result of changes in patterns of feed intake and growth since that work was conducted. For example, in 1996, Ross I broilers grown to $42 \mathrm{~d}$ ate $30 \%(1.08 \mathrm{~kg})$ of their total feed consumption during the first $21 \mathrm{~d}$ (Ross Breeders, 1996), however, the figure for the current genotype is only $25 \%(1.02 \mathrm{~kg})$; a marked and surprising reduction in both percentage and absolute terms considering that total feed intake to $42 \mathrm{~d}$ has increased by about $0.40 \mathrm{~kg}$ over the same period (Aviagen, 2007). Meat-type poultry on short photoperiods learn to eat in the dark to satisfy their desire for food (Morris, 1967; Lewis et al., 1998) and, when kept in total darkness from $7 \mathrm{~d}$, have been observed to have a feed intake and body weight similar to LL birds (Cherry \& Barwick, 1962). Thus, an alternative scenario for the improved 
performance to $21 \mathrm{~d}$ under $8 \mathrm{~h}$ is that the genetically larger appetite and faster growth of the modern broiler (McKay et al., 2000) has forced it to eat in the dark at a younger age than did its predecessors, thus avoiding

Table 1 Mean body weight, feed intake and feed conversion ratio 0-21 d, 22-42 d, and 0-42 d for Cobb 500 and Ross 308 females maintained on 8- or 16-h photoperiods, or given 8-h photoperiods to $21 \mathrm{~d}$ and 16 -h photoperiods from 22 to $42 \mathrm{~d}$ (INC)

\begin{tabular}{|c|c|c|c|c|}
\hline Breed & Lighting treatment & $\begin{array}{l}\text { Body weight } \\
\text { (g) }\end{array}$ & $\begin{array}{l}\text { Feed intake } \\
(\mathrm{g} / \mathrm{bird})\end{array}$ & $\begin{array}{l}\text { Feed conversion } \\
\text { ratio }(\mathrm{g} / \mathrm{g})\end{array}$ \\
\hline & \multicolumn{4}{|c|}{$0-21 d$} \\
\hline \multirow[t]{3}{*}{ Ross } & constant $8 \mathrm{~h}$ & 856 & 1163 & 1.44 \\
\hline & constant $16 \mathrm{~h}$ & 865 & 1176 & 1.44 \\
\hline & INC & 858 & 1198 & 1.47 \\
\hline \multirow[t]{3}{*}{ Cobb } & constant $8 \mathrm{~h}$ & 887 & 1152 & 1.37 \\
\hline & constant $16 \mathrm{~h}$ & 897 & 1188 & 1.39 \\
\hline & INC & 880 & 1165 & 1.39 \\
\hline \multirow[t]{6}{*}{ Mean } & constant $8 \mathrm{~h}$ & 871 & 1158 & 1.40 \\
\hline & constant $16 \mathrm{~h}$ & 881 & 1182 & 1.42 \\
\hline & INC & 869 & 1158 & 1.43 \\
\hline & $P$ value & 0.577 & 0.210 & 0.402 \\
\hline & Pooled s.e.d. & 12.3 & 14.1 & 0.020 \\
\hline & \multicolumn{4}{|c|}{$22-42 d$} \\
\hline \multirow[t]{3}{*}{ Ross } & constant $8 \mathrm{~h}$ & 1681 & 3835 & 2.28 \\
\hline & constant $16 \mathrm{~h}$ & 1512 & 3709 & 2.46 \\
\hline & INC & 1658 & 3761 & 2.27 \\
\hline \multirow[t]{3}{*}{ Cobb } & constant $8 \mathrm{~h}$ & 1636 & 3724 & 2.28 \\
\hline & constant $16 \mathrm{~h}$ & 1580 & 3627 & 2.29 \\
\hline & INC & 1656 & 3663 & 2.21 \\
\hline \multirow[t]{6}{*}{ Mean } & constant $8 \mathrm{~h}$ & $1659^{\mathrm{a}}$ & $3779^{a}$ & $2.28^{\mathrm{b}}$ \\
\hline & constant $16 \mathrm{~h}$ & $1546^{\mathrm{b}}$ & $3668^{\mathrm{b}}$ & $2.38^{\mathrm{a}}$ \\
\hline & INC & $1657^{\mathrm{a}}$ & $3712^{a b}$ & $2.24^{\mathrm{b}}$ \\
\hline & $P$ value & 0.004 & 0.038 & 0.024 \\
\hline & Pooled s.e.d. & 31.8 & 38.9 & 0.044 \\
\hline & \multicolumn{4}{|c|}{$0-42 \mathrm{~d}$} \\
\hline \multirow[t]{3}{*}{ Ross } & constant $8 \mathrm{~h}$ & 2537 & 4998 & 2.01 \\
\hline & constant $16 \mathrm{~h}$ & 2378 & 4885 & 2.10 \\
\hline & INC & 2516 & 4954 & 2.01 \\
\hline \multirow[t]{3}{*}{ Cobb } & constant $8 \mathrm{~h}$ & 2523 & 4876 & 1.97 \\
\hline & constant $16 \mathrm{~h}$ & 2478 & 4815 & 1.98 \\
\hline & INC & 2535 & 4827 & 1.94 \\
\hline \multirow[t]{5}{*}{ Mean } & constant $8 \mathrm{~h}$ & $2530^{\mathrm{a}}$ & 4937 & $1.99^{\mathrm{ab}}$ \\
\hline & constant $16 \mathrm{~h}$ & $2428^{b}$ & 4850 & $2.04^{\mathrm{a}}$ \\
\hline & INC & $2526^{a}$ & 4891 & $1.97^{\mathrm{b}}$ \\
\hline & $\mathrm{P}$ value & 0.018 & 0.151 & 0.072 \\
\hline & Pooled s.e.d. & 34.9 & 41.8 & 0.028 \\
\hline
\end{tabular}

\footnotetext{
${ }^{\mathrm{a}, \mathrm{b}}$ Within columns, means with different superscripts are significantly different at $\mathrm{P}<0.05$
}

Res $\mathrm{df}=14$ for all analyses 
Table 2 Total mortality, and incidence of culling and leg problems 0-21 d, 22-42 d, and 0-42 d for Cobb 500 and Ross 308 females maintained on 8- or 16-h photoperiods, or given 8-h photoperiods to $21 \mathrm{~d}$ and $16-\mathrm{h}$ photoperiods from 22 to $42 \mathrm{~d}$ (INC)

\begin{tabular}{|c|c|c|c|c|}
\hline Breed & Lighting treatment & Total mortality (\%) & Culls (\%) & Leg problems $(\%)$ \\
\hline & \multicolumn{4}{|c|}{$0-21 d$} \\
\hline \multirow[t]{3}{*}{ Ross } & constant $8 \mathrm{~h}$ & 2.7 & - & - \\
\hline & constant $16 \mathrm{~h}$ & 2.7 & - & - \\
\hline & INC & 2.0 & - & - \\
\hline \multirow{3}{*}{ Cobb } & constant $8 \mathrm{~h}$ & 2.5 & - & - \\
\hline & constant $16 \mathrm{~h}$ & 2.5 & - & - \\
\hline & INC & 2.3 & - & - \\
\hline \multirow[t]{6}{*}{ Mean } & constant $8 \mathrm{~h}$ & 2.6 & - & - \\
\hline & constant $16 \mathrm{~h}$ & 2.6 & - & - \\
\hline & INC & 2.2 & - & - \\
\hline & $P$ value & 0.599 & & \\
\hline & Pooled s.e.d. & 0.85 & & \\
\hline & \multicolumn{4}{|c|}{$22-42 d$} \\
\hline \multirow[t]{3}{*}{ Ross } & constant $8 \mathrm{~h}$ & 1.0 & 0.0 & 0.3 \\
\hline & constant $16 \mathrm{~h}$ & 2.2 & 0.3 & 0.5 \\
\hline & INC & 1.5 & 0.3 & 0.2 \\
\hline \multirow[t]{3}{*}{ Cobb } & constant $8 \mathrm{~h}$ & 2.8 & 1.3 & 1.7 \\
\hline & constant $16 \mathrm{~h}$ & 3.0 & 0.7 & 0.7 \\
\hline & INC & 3.2 & 0.5 & 0.8 \\
\hline \multirow[t]{6}{*}{ Mean } & constant $8 \mathrm{~h}$ & 1.9 & 0.7 & 1.0 \\
\hline & constant $16 \mathrm{~h}$ & 2.6 & 0.5 & 0.6 \\
\hline & INC & 2.3 & 0.4 & 0.5 \\
\hline & $P$ value & 0.678 & 0.737 & 0.244 \\
\hline & Pooled s.e.d. & 0.75 & 0.32 & 0.30 \\
\hline & \multicolumn{4}{|c|}{$0-42 d$} \\
\hline \multirow{3}{*}{ Ross } & constant $8 \mathrm{~h}$ & 3.7 & 0.0 & 0.3 \\
\hline & constant $16 \mathrm{~h}$ & 4.8 & 0.3 & 0.5 \\
\hline & INC & 3.5 & 0.3 & 0.2 \\
\hline \multirow[t]{3}{*}{ Cobb } & constant $8 \mathrm{~h}$ & 5.3 & 1.3 & 1.7 \\
\hline & constant $16 \mathrm{~h}$ & 5.5 & 0.7 & 0.7 \\
\hline & INC & 5.5 & 0.5 & 0.8 \\
\hline \multirow[t]{5}{*}{ Mean } & constant $8 \mathrm{~h}$ & 4.5 & 0.7 & 1.0 \\
\hline & constant $16 \mathrm{~h}$ & 5.2 & 0.5 & 0.6 \\
\hline & INC & 4.5 & 0.4 & 0.5 \\
\hline & $P$ value & 0.644 & 0.737 & 0.244 \\
\hline & Pooled s.e.d. & 0.81 & 0.32 & 0.30 \\
\hline
\end{tabular}

\footnotetext{
${ }^{a, b}$ Within columns, means with different superscripts are significantly different at $\mathrm{P}<0.05$

Res $\mathrm{df}=14$ for all analyses

the suppression of feed intake and growth before $21 \mathrm{~d}$ observed in earlier studies. As soon as short-day birds have learnt to eat during the scotoperiod, they are obviously able to feed continuously, as if on LL, and to eat to their potential. In contrast, 16-h birds may be able to satisfy their hunger without eating in the dark, but the shorter feeding time inevitably leads to a lower feed intake, despite a theoretical higher energy expenditure
} 
(MacLeod et al., 1988), and a reduction in final body weight. Although eating in the dark may not be the complete explanation for the difference in feed intake under 8- and 16-h photoperiods between 22 and $42 \mathrm{~d}$, it does emphasize the importance of ensuring that feed is available throughout the dark period when commercial birds are kept on short days. The non-significant difference in feed conversion efficiency between the constant 8- and 16-h groups agrees with the findings of Gordon \& Tucker (1995).

Table 3 Mean body weight, feed intake, feed conversion ratio, mortality and incidence of leg problems 0-21 d, 22-42 d, and 0-42 d for Cobb 500 and Ross 308 females, with data pooled for the three lighting treatments

\begin{tabular}{|c|c|c|c|c|c|}
\hline Breed & $\begin{array}{l}\text { Body weight } \\
\text { (g) }\end{array}$ & $\begin{array}{l}\text { Feed intake } \\
(\mathrm{g} / \mathrm{bird})\end{array}$ & $\begin{array}{l}\text { Feed conversion } \\
\text { ratio }(\mathrm{g} / \mathrm{g})\end{array}$ & $\begin{array}{c}\text { Total mortality } \\
(\%)\end{array}$ & Leg problems (\%) \\
\hline & \multicolumn{5}{|c|}{$0-21 d$} \\
\hline Ross & $860^{b}$ & 1177 & $1.45^{\mathrm{a}}$ & 2.4 & 0 \\
\hline Cobb & $888^{\mathrm{a}}$ & 1168 & $1.39^{\mathrm{b}}$ & 2.4 & 0 \\
\hline$P$ value & 0.013 & 0.448 & 0.002 & 1.000 & - \\
\hline \multirow[t]{2}{*}{ Pooled s.e.d. } & 10.0 & 11.5 & 0.017 & 0.315 & - \\
\hline & \multicolumn{5}{|c|}{$22-42 d$} \\
\hline Ross & 1617 & $3768^{\mathrm{a}}$ & 2.34 & $1.6^{\mathrm{b}}$ & $0.3^{\mathrm{b}}$ \\
\hline Cobb & 1624 & $3671^{b}$ & 2.26 & $3.0^{\mathrm{a}}$ & $1.1^{\mathrm{a}}$ \\
\hline$P$ value & 0.794 & 0.009 & 0.058 & 0.034 & 0.011 \\
\hline \multirow[t]{2}{*}{ Pooled s.e.d } & 26.0 & 31.8 & 0.036 & 0.62 & 0.25 \\
\hline & \multicolumn{5}{|c|}{$0-42 d$} \\
\hline Ross & 2477 & $4946^{\mathrm{a}}$ & $2.04^{\mathrm{a}}$ & $4.0^{\mathrm{b}}$ & $0.3^{\mathrm{b}}$ \\
\hline Cobb & 2512 & $4839^{b}$ & $1.96^{\mathrm{b}}$ & $5.4^{\mathrm{a}}$ & $1.1^{\mathrm{a}}$ \\
\hline$P$ value & 0.235 & 0.008 & 0.005 & 0.034 & 0.011 \\
\hline Pooled s.e.d. & 28.5 & 34.1 & 0.023 & 0.62 & 0.25 \\
\hline
\end{tabular}

${ }^{\mathrm{a}, \mathrm{b}}$ Within columns, means with different superscripts are significantly different at $\mathrm{P}<0.05$

Res $\mathrm{df}=14$ for all analyses

The previous work with step-up lighting programmes, which invariably included an increase from 6 to $23 \mathrm{~h}$ at $21 \mathrm{~d}$ (Classen \& Riddell, 1989, Classen et al., 1991; Renden et al., 1991; 1992; 1993; 1996; Blair et al., 1993) showed that feed intakes and body weights were usually lower at $21 \mathrm{~d}$, but similar at 42 and $49 \mathrm{~d}$, to those of birds maintained throughout on $23 \mathrm{~h}$. Although the differences in body weight at $21 \mathrm{~d}$ failed to reach significance in some of these earlier trials, a paired- $t$ test of all the data showed a significant reduction in body weight at $21 \mathrm{~d}(\mathrm{P}<0.001)$, but no significant difference at $42 \mathrm{~d}(\mathrm{P}=0.527)$. The trials generally involved only males, and it was suggested that the compensatory feed intake and growth after $21 \mathrm{~d}$ were consequences of an increased production of anabolic steroids following the transfer from 6 to $23 \mathrm{~h}$ (Classen, 1992). Physical feed restriction during the early growing period has also resulted in compensatory growth in the later stages (Plavnik \& Hurwitz, 1985; 1988), but the findings of the current trial question this conclusion and offer an alternative explanation. The similarity of the feed intakes and body weights for the 8- and 16-h treatments at $21 \mathrm{~d}$ meant that no compensatory growth was required between 22 and $42 \mathrm{~d}$; yet both the constant 8-h and the photostimulated groups had higher feed intakes and larger body weight gains in that period than 16-h birds. Notwithstanding that broiler females can experience a photosexual response at $21 \mathrm{~d}$ (Dunn et al., 1990), there is doubt as to the relevance of this phenomenon because a transfer from 6 to $23 \mathrm{~h}$ is predicted to have minimal effect on gonadal development (Lewis \& Morris, 2004), and both the photostimulated ( 8 to $16 \mathrm{~h}$ ) and un-photostimulated (constant $8 \mathrm{~h}$ ) groups in this trial out-performed the constant 16-h birds after $21 \mathrm{~d}$ (Table 1). The alternative explanation is that birds on $8 \mathrm{~h}$ learned to eat in dark during the initial $21 \mathrm{~d}$, but those on 16-h days did not, and the photostimulated birds continued to use the talent during the final $21 \mathrm{~d}$, even though they were receiving $16 \mathrm{~h}$ of light. Unfortunately, none of the early 
studies included a constant short-day control, so comparisons can only be with $23 \mathrm{~h}$ photoperiods, and the possibility that dark-time feeding was the explanation cannot be explored.

The significantly more efficient feed conversion of the photostimulated birds, relative to the constant 16-h controls, agrees with the numerically superior difference observed by Renden et al. (1993), but disagrees with the similar conversion efficiencies reported for these treatments by Renden et al. (1992). There were no direct comparisons of increasing photoperiod with constant $16 \mathrm{~h}$ in the other studies, because the long-day control was always $23 \mathrm{~h}$. Nevertheless, a paired-t test of all data (Classen \& Riddell, 1989; Classen et al., 1991; Renden et al., 1992; 1993; Blair et al., 1993) showed a strong tendency towards more efficient feed conversion for birds transferred from 6 to $23 \mathrm{~h}(\mathrm{P}=0.075)$.

The main benefits to be obtained from a step-up lighting programme for broilers, be it an abrupt or gradual increase, are improved liveability and fewer leg abnormalities, and these are thought to arise from slower initial growth, because the same improvements in health and skeletal integrity have been reported for birds that had their initial growth restricted by dietary energy control (Haye \& Simmons, 1978) or by exposure to shorter daylengths (Gordon \& Tucker, 1995). A paired- $t$ test of five sets of data from earlier step-up lighting research suggested that the incidence of leg problems was generally about half that of birds given 23-h daylengths $(\mathrm{P}=0.069)$. The lack of a lighting effect on bird health in this trial (Table 2) may be due to a combination of the generally low mortality and small incidence of leg problems, female birds having better liveability and fewer leg disorders than males (most of the earlier work used males), the long photoperiod being $16 \mathrm{~h}$ (which has been shown to have fewer deaths and leg troubles than the $23 \mathrm{~h}$ used in previous trials), and the initial growth in the short day and step-up groups being similar to the 16-h controls.

Although the slower initial growth of the Ross birds, compared with Cobb, may have been a consequence of genetic selection, it was not the result of a smaller feed intake but of inferior feed conversion efficiency, and this continued throughout the trial (Table 3 ). The significantly lower mortality and incidence of leg disorders in the Ross birds in the $22-42 \mathrm{~d}$ period may have been a consequence of their significantly slower growth during the first $21 \mathrm{~d}$.

\section{References}

Analytical Software, 2003. StatistixVersion 8, Tallahassee, FL 32317, USA.

Aviagen, 2007. www.aviagen.com/broiler308po/broilerPO308.

Beane, W.L., Siegel, P.B. \& Siegel, H.S., 1962. The effect of light on body weight and feed conversion of broilers. Poult. Sci. 41, 1350-1351.

Beane, W.L., Siegel, P.B. \& Siegel, H.S., 1965. Light environment as a factor in growth and feed efficiency of meat-type chickens. Poult. Sci. 44, 1009-1012.

Blair, R., Newberry, R.C. \& Gardiner, E.E., 1993. Effects of lighting pattern and dietary tryptophan supplementation on growth and mortality in broilers. Poult. Sci. 72, 495-502.

Buckland, R.B., Bernon, D.E. \& Goldrosen, A., 1976. Effect of four lighting regimes on broiler performance, leg abnormalities and plasma corticoid levels. Poult. Sci. 55, 1072-1076.

Cherry, P. \& Barwick, M.W., 1962. The effect of light on broiler growth. II. Light patterns. Br. Poult. Sci. 3 , 41-50.

Classen, H.L., 1992. Management of leg disorders. In: Bone biology and skeletal disorders in poultry. Ed. Whitehead, C.C., Carfax Publishing Company, Abingdon. pp. 195-211.

Classen, H.L. \& Riddell, C., 1989. Photoperiodic effects on performance and leg abnormalities in broiler chickens. Poult. Sci. 68, 873-879.

Classen, H.L., Riddell, C. \& Robinson, F.E., 1991. Effects of increasing photoperiod length on performance and health of broiler chickens. Br. Poult. Sci. 32, 21-29.

Dunn, I.C., Sharp, P.J. \& Hocking, P.M., 1990. Effects of interactions between photostimulation, dietary restriction and dietary maize oil dilution on plasma LH and ovarian and oviduct weights in broiler breeder females during rearing. Br. Poult. Sci. 31, 415-427.

Gordon, S.H. \& Tucker, S.A., 1995. Effect of daylength on broiler welfare. Br. Poult. Sci. 36, 844-845.

Haye, U. \& Simons, P.C.M., 1978. Twisted legs in broilers. Br. Poult. Sci. 19, 549-557.

Jensen, L.S. \& Matson, W.E., 1957. Enlargement of avian eye by subjecting chicks to continuous incandescent illumination. Science 125, 741. 
Lewis, P.D. \& Morris, T.R., 2004. Research note: amendments to the model for predicting age at sexual maturity for growing pullets of layer strains following changes in photoperiod. J. Agric. Sci. 142, 613-614.

Lewis, P.D., Perry, G.C. \& Sherwin, C.M., 1998. Effect of photoperiod and light intensity on the performance of intact male turkeys. Anim. Sci. 66, 759-767.

Li, T., Troilo, D., Glasser, A. \& Howland, H.C., 1995. Constant light produces severe corneal flattening and hyperopia in chickens. Vision Res. 35, 1203-1209.

MacLeod, M.G., Jewitt, T.R. \& Anderson, J.E.M., 1988. Energy expenditure and physical activity in domestic fowl kept on standard and interrupted lighting patterns. Br. Poult. Sci. 29, 231-244.

McKay, J.C., Barton, N.F., Koerhuis, A.N.M. \& McAdam, J., 2000. The challenge of genetic change in the broiler chicken. In: The challenge of genetic change in animal production. Eds. Hill, W.G., Bishop, S.C., McGuirk, B., McKay, J.C., Simm, G. \& Webb, A.J., 2000. Occ. Publi. Br. Soc. Animal Sci. No. 27. pp. 1-7.

Moore, C.H., 1957. The effect of light on growth of broiler chickens. Poult. Sci. 36, 1142.

Morris, T.R., 1967. Light requirements of the fowl. In: Environmental control in poultry production. Oliver \& Boyd, Edinburgh. pp. 15-39.

Oishi, T. \& Murakami, N. 1985., Effects of duration and intensity of illumination on several parameters of the chick eye. Comp. Biochem. \& Physiol. A 81, 319-323.

Plavnik, I. \& Hurwitz, S., 1985. The performance of broiler chicks during and following a severe feed restriction at an early age. Poult. Sci. 64, 348-355.

Plavnik, I. \& Hurwitz, S., 1988. Early feed restriction in chicks: effect of age, duration, and sex. Poult. Sci. $67,384-390$

Renden, J.A., Bilgili, S.F., Lien, R.J. \& Kincaid, S.A., 1991. Live performance and yields of broilers provided various lighting schedules. Poult. Sci. 70, 2055-2062.

Renden, J.A., Bilgili, S.F. \& Kincaid, S.A., 1992. Live performance and carcass yield of broiler strain crosses provided either 16 or 23 hours of light per day. Poult. Sci. 71, 1427-1435.

Renden, J.A., Bilgili, S.F. \& Kincaid, S.A., 1993. Comparison of restricted and increasing light programs for male broiler performance and carcass yield. Poult. Sci. 72, 378-382.

Renden, J.A., Moran, E.T. \& Kincaid, S.A., 1996. Lighting programs for broilers that reduce leg problems without loss of performance or yield. Poult. Sci. 75, 1345-1350.

Shutze, J.V., Jensen, L.S., Carver, J.S. \& Matson, W.E., 1960. Influence of various lighting regimes on the performance of broiler chickens. Washington Agric. Expt. Stn. Tech. Bull. 36, pp. 1-11.

Skoglund, W.C., Warbeck, C.J. \& Palmer, D.H., 1966. Length of light period for maximum broiler weight. Poult. Sci. 45, 1185-1189.

Stone, R.A., Lin, T., Desai, D. \& Capehart, C., 1995. Photoperiod, early post-natal eye growth, and visual deprivation. Vision Res. 35, 1195-1202.

Weaver, W.D. \& Siegel, P.B., 1968. Photoperiodism as a factor in feeding rhythms of broiler chickens. Poult. Sci. 47, 1148-1154.

Whitley, R.D., Albert, R.A., Brewer, R.N., McDaniel, G.R., Pidgeon, G.L. \& Mora, E.C., 1984. Photoinduced buphthalmic avian eyes. I. Continuous fluorescent light. Poult. Sci. 63, 1537-1542.

Wise, D.R., 1970. Comparisons of the skeletal systems of growing broiler and layer strain chickens. Br. Poult. Sci. 11, 333-339. 